\title{
Development of Meat based Seasoning Fryums using Chicken Meat and Rice Flour Blends
}

\author{
M. Anna Anandh* \\ Department of Livestock Products Technology, Tamil Nadu Veterinary and \\ Animal Sciences University-Veterinary College and Research Institute, \\ Orathanadu-614 625, Thanjavur District, Tamil Nadu, India \\ *Corresponding author
}

\section{A B S T R A C T}

Meat based seasoning fryums (meat vadam) with 15,25 and $35 \%$ chicken meat were developed and their quality evaluated. Fryums prepared with $100 \%$ rice flour

Keywords

Chicken, Meat, Fryums, Vadam, Quality, Acceptability.

Article Info

Accepted:

26 May 2017

Available Online:

10 June 2017 were used as control. Linear and significantly $(\mathrm{P}<0.01)$ increased values were observed from control to chicken meat incorporated seasoning fryums for $\mathrm{pH}$, product yield, bulk density, moisture, protein and fat contents. Significantly $(\mathrm{P}<0.01)$ reverse trends were observed for hydratability, water absorption index and water solubility index. Results of sensory evaluation on 8 - point hedonic scale showed appearance and colour, flavour, texture, crispness, after taste, meat flavour intensity and overall palatability were higher for $25 \%$ chicken meat incorporated seasoning fryums followed by $15 \%$ and $35 \%$ chicken meat incorporated seasoning fryums. Sensory evaluation results indicated that chicken meat incorporated seasoning fryums were rated "very palatable" to "moderately palatable". Thus, it can be concluded that, $25 \%$ chicken meat can be successfully used preparation of meat based seasoning fryums.

\section{Introduction}

Left over rice vathals or Vattals or vadams is a sun-dried product which can be stored for over a year. Vadam is traditionally made using left over rice. They are deep fried and served as a rice fryums an accompaniment along with rice and rasam or sambar. They are also served at meals, especially on festive occasions. They are equally loved by both adults and children and also make a good evening snack or at tea-time as snacks. Most of the vadam available in the market are mainly based of cereals which are high in calorie and low in protein contents.
Incorporation of animal proteins in such snack type food products can improve the nutritional quality especially with respect to amino acid composition, flavor, odor and taste (Kumar et al., 2016). Incorporation of meat in these snacks type product is a good alteration in its nutritional value particularly high value animal protein (Anna Anandh et al., 2005; Singh et al., 2011).

It is observed that in South Indian household is prepared by using leftover cooked rice, which is soaked in excess water and allowed 
to ferment overnight. The water is drained and rice is mashed and finely cut onions, chillies and lime are added and it is made into small vadam and sun - dried.

Taking a clue from this practice and in order to diversify the available product range, the cost effective recipe for chicken meat based seasoning fryums/vadam was standardized and their quality characteristics were evaluated. In this study, a scientific approach was made to develop chicken meat based fryums with different level of chicken meat.

\section{Materials and Methods}

\section{Chicken meat}

Deboned chicken meat was purchased from the local chicken meat stall. It was cut into small chunks and frozen for 1-2 h to ensure easy mincing.

The chicken meat chunks were minced twice through the meat mincer and the minced meat was used in the preparation of chicken meat based seasoning fryums.

\section{Product formulation and treatments}

The formula for chicken meat based seasoning fryums was developed after conducting a series of preliminary trails. The basic product formulation consists of rice flour, common salt, green chili paste, onion paste, cumin powder, spice mix, asafetida powder and curd. Chicken meat based seasoning fryums prepared with incorporation of 15,25 and $35 \%$ minced chicken meat. The corresponding levels of rice flour were $85 \%$, $75 \%$ and $65 \%$ in the respective formulations. Other ingredients used in the formulation i.e., common salt, green chili paste, onion paste, cumin powder, spice mix, asafetida powder and curd were added over and above rice flour and chicken meat combination. Control seasoning fryums contained $100 \%$ rice flour and no chicken meat (Table 1).

\section{Process schedule}

Required quantity of water $(250 \%$ of the flour used) boiled to boiling temperature. Rice flour slowly added to boiling water and stir continuously and mixed thoroughly to form a slurry without lumps in low flame. Then green chili paste, onion paste, cumin powder, spice mixture and asafetida powder were added in dough and mix well. Followed by addition of minced chicken meat in to the dough and cooked for $5 \mathrm{~min}$ and then cover and cool the dough. After cooling, curd was added and kneads it to soft dough. The dough was extruded through a manually operated stainless steel extruder into ribbon shape on a clean white cloth. Once the fryums were spread out, it was kept in a clean environment for sun drying for about 4 days to drain out the moisture content completely. The dried seasoning frymus was deep oil fried for about 30 seconds at $150 \pm 1^{\circ} \mathrm{C}$. The fried fryums were served immediately to a panel for evaluation of various sensory attributes on an 8 - point hedonic scale.

\section{Physico chemical analysis}

\section{Proximate analysis}

The moisture, protein and fat contents of control and chicken meat based seasoning fryums were determined by standard methods using hot air oven, Kjeldahl's assembly and soxhlet ether extraction apparatus, respectively (AOAC, 1995).

\section{PH}

The $\mathrm{pH}$ of control and chicken meat based seasoning fryums were determined by using digital $\mathrm{pH}$ meter. 
Homogenates were prepared by blending $10 \mathrm{~g}$ sample with $90 \mathrm{ml}$ distilled water using a tissue homogenizer for $1 \mathrm{~min}$. The $\mathrm{pH}$ of the homogenates was recorded by immersing combined glass electrode of digital $\mathrm{pH}$ meter (Century Instruments Ltd, India).

\section{Product yield}

The weight of control and chicken meat based seasoning fryums were recorded before drying and after frying and the yield was calculated (product yield $=$ weight of dried products / weight of raw products $\times 100$ ) and expressed as percentage.

\section{Bulk density}

Bulk density of control and chicken meat based seasoning fryums were determined based on the procedure of described by Mittal and Lawrie (1986). Pieces of extrudates were assumed to be cylindrical in shape and the volume was calculated using the formula of II r2 (II X radius $2 X$ length). The extrudate of known length was weighed and bulk density was calculated as mass / volume ( $\mathrm{g} / \mathrm{cm} \mathrm{-3)}$.

\section{Hydratability}

Hydratability of control and chicken meat based seasoning fryums were determined based on the procedure of Mittal and Lawrie (1986). Weighed pieces of products (approximately $2.5 \mathrm{~g}$ ) were placed in test tubes with excess boiling water for $5 \mathrm{~min}$ to hydrate the sample. The hydrated samples were drained for $5 \mathrm{~min}$, blotted and weighed. Hydratability of control and chicken meat seasoning fryums were estimated as weight of water absorbed / weight of dry sample (g/g).

\section{Water absorption index}

Water absorption index was measured according to the method described by
Anderson et al., (1969). $2.5 \mathrm{~g}$ of ground sample was weighed in $100 \mathrm{ml}$ centrifuge tubes, $30 \mathrm{ml}$ of distilled water was added and the sample was left equilibrated for $30 \mathrm{~min}$ with occasional stirring. After centrifugation at $3000 \mathrm{rpm}$ for $10 \mathrm{~min}$, the supernatant was carefully poured into the Petri dish and the remaining gel was weighed. The water absorption index calculated as the ratio of gel obtained to that of initial weight of sample $(\mathrm{g} / \mathrm{g})$.

\section{Water solubility index}

The water solubility index was measured according to the method described by Machado et al., (1998). The supernatant liquid obtained from water absorption index determination was used for determination of water solubility index. The supernatant liquid was kept in hot air oven to evaporate to dryness. After drying, the petri dishs were cooled and weighed. The water solubility index was calculated as weight of solids to the initial weight of the sample $(\mathrm{g} / \mathrm{g})$.

\section{Sensory evaluation}

Sensory evaluation was conducted with semitrained panelists. Control and chicken meat based seasoning fryums were served to the panelists. The sensory attributes like appearance and colour, flavour, texture, crispness, after taste, meat flavour intensity and overall palatability were evaluated on 8 point descriptive scale (where in 1 is extremely undesirable and 8 is extremely desirable) as suggested by Keeton (1983).

\section{Statistical analysis}

The experiment was repeated four times. The data generated from each trial were analyzed statistically by following standard procedures (Snedecor and Cochran, 1989) for comparing 
the means and to determine the effect of treatment.

\section{Results and Discussion}

\section{Physico-chemical characteristics}

Results of physico - chemical parameters of control and chicken meat based seasoning fryums are presented in Table 2 . The values for $\mathrm{pH}$ progressively and significantly increased from control to treatments. Significantly higher $\mathrm{pH}$ value was observed in $35 \%$ chicken meat incorporated seasoning fryums followed by $25 \%$ and $15 \%$ chicken meat incorporated seasoning fryums and control. The $\mathrm{pH}$ value of chicken meat based seasoning fryums could be attributed to increased level of meat in the product formulation. The product yield increased significantly from control to chicken meat incorporated seasoning fryums. Among chicken meat based seasoning fryums, higher product yield observed in $35 \%$ chicken meat incorporated seasoning fryums followed by $25 \%$ and $15 \%$ chicken meat incorporated seasoning fryums. The increased product yield of chicken meat incorporated seasoning fryums could be attributed due to incorporation of chicken meat in the product. The bulk density values of control and chicken meat incorporated seasoning fryums differ significantly between them and the value were significantly $(\mathrm{P}<0.01)$ increasing with increasing level of chicken meat in the formulation. Among chicken meat incorporated seasoning fryums, bulk density value was higher in $35 \%$ chicken meat incorporated seasoning fryums followed by $25 \%$ and $15 \%$ chicken meat incorporated seasoning fryums and control. Increased moisture content of extrudate contributed to increased bulk density (Barrett and Ross, 1990; Kavya Reddy et al.,. 2014). Breen et al., (1977) reported that combination of high concentration of starch, high protein and high fiber snack foods tend to decreased the bulk density. The present findings are in agreement with the above findings. The value of hydratability values decreased significantly from control to chicken meat incorporated seasoning fryums. Among chicken meat based seasoning fryums, higher hydratability value observed in $15 \%$ chicken meat incorporated seasoning fryums followed by $25 \%$ and $35 \%$ chicken meat incorporated seasoning fryums. These finding are in conformity with those of Mittal and Lawrie (1984) who reported that presence of meat in extrudates lowered the ability of hydrate the products. Water absorption index value was significantly $(\mathrm{P}<0.01)$ higher in control as compared chicken meat incorporated seasoning fryums. Among chicken meat incorporated seasoning fryums, higher water absorption index value observed in $15 \%$ chicken meat incorporated seasoning fryums followed by $25 \%$ and $35 \%$ chicken meat incorporated seasoning fryums and the value differ significantly between them.

This is in agreement with findings of Davidson et al., (1984) and Cheftel (1986). They reported that when starch was used in large quantity, water absorption index of extrudates increased due to increased starch gelatinization. Park et al., (1993) also reported that high starch and low fat level resulted in higher water absorption index of products. Water solubility index significantly decreased from control to chicken meat incorporated seasoning fryums. Higher water solubility index value was observed in control followed by $15 \%, 25 \%$ and $35 \%$ chicken meat incorporated seasoning fryums.

Water solubility index of control and chicken meat incorporated seasoning fryums differed significantly between them. The high water solubility index of control as compared to chicken meat based seasoning fryums could be attributed to higher level of starch with 
increased fragmentation and starch conversion resulting in higher water solubility characteristics (Gomez and Aguilera, 1983; Wen et al., 1990; Siriburi and Hill, 2000). The results of this present study are also in conformity with above findings.

Mean moisture, protein and fat contents chicken meat incorporated extruded seasoning fryums significantly $(\mathrm{P}<0.01)$ higher as compared to control. Mean moisture contents progressively and significantly increased from control to treatments. Significantly lower moisture contents observed in control as compared to chicken meat incorporated seasoning fryums. Jean et al., (1996) reported that snack foods should have moisture content of less than $5 \%$ to make the product brittle. Though the chicken meat incorporated seasoning fryums of this study showed slightly higher moisture content.

Table.1 Formulation of seasoning fryums incorporated with chicken meat

\begin{tabular}{|l|c|c|c|c|}
\hline \multirow{2}{*}{ Ingredients } & \multirow{2}{*}{ Control (\%) } & \multicolumn{3}{|c|}{ Level of chicken meat (\%) } \\
\cline { 3 - 5 } & & $\mathbf{1 5}$ & $\mathbf{2 5}$ & $\mathbf{3 5}$ \\
\hline Chicken Meat & - & 15 & 25 & 35 \\
\hline Rice flour & 100 & 85 & 75 & 65 \\
\hline Common salt & 2.5 & 2.5 & 2.5 & 2.5 \\
\hline Green chili paste & 1.0 & 1.0 & 1.0 & 1.0 \\
\hline Cumin powder & 0.5 & 0.5 & 0.5 & 0.5 \\
\hline Asafetida powder & 0.5 & 0.5 & 0.5 & 0.5 \\
\hline Onion paste & 20 & 20 & 20 & 20 \\
\hline Spice mix & 1.5 & 1.5 & 1.5 & 1.5 \\
\hline Curd & 25 & 25 & 25 & 25 \\
\hline
\end{tabular}

Water: $250 \%$ of the rice flour (on weight basis)

Table.2 Physico-chemical characteristics of seasoning fryums incorporated with chicken meat $($ Mean \pm SE)

\begin{tabular}{|l|c|c|c|c|}
\hline \multirow{2}{*}{ Parameters } & \multirow{2}{*}{ Control } & \multicolumn{3}{|c|}{ Level of chicken meat (\%) } \\
\cline { 3 - 5 } & & $\mathbf{1 5}$ & $\mathbf{2 5}$ & $\mathbf{3 5}$ \\
\hline $\mathrm{pH}$ & $6.23 \pm 0.02^{\mathrm{a}}$ & $6.47 \pm 0.03^{\mathrm{b}}$ & $6.59 \pm 0.01^{\mathrm{c}}$ & $6.65 \pm 0.02^{\mathrm{d}}$ \\
\hline Product yield (\%) & $41.32 \pm 0.14^{\mathrm{a}}$ & $46.14 \pm 0.16^{\mathrm{b}}$ & $52.46 \pm 0.12^{\mathrm{c}}$ & $57.28 \pm 0.12^{\mathrm{d}}$ \\
\hline Bulk density (g/cm-3) & $2.35 \pm 0.02^{\mathrm{a}}$ & $2.44 \pm 0.04^{\mathrm{b}}$ & $2.69 \pm 0.02^{\mathrm{c}}$ & $2.86 \pm 0.04^{\mathrm{d}}$ \\
\hline Hyratability (g/g) & $2.74 \pm 0.02^{\mathrm{a}}$ & $2.62 \pm 0.01^{\mathrm{b}}$ & $1.97 \pm 0.02^{\mathrm{c}}$ & $1.46 \pm 0.02^{\mathrm{d}}$ \\
\hline Water absorption index (g/g) & $6.90 \pm 0.01^{\mathrm{a}}$ & $5.95 \pm 0.02^{\mathrm{b}}$ & $4.87 \pm 0.01^{\mathrm{c}}$ & $4.12 \pm 0.04^{\mathrm{d}}$ \\
\hline Water solubility index (g/g) & $1.17 \pm 0.01^{\mathrm{a}}$ & $0.94 \pm 0.01^{\mathrm{b}}$ & $0.93 \pm 0.02^{\mathrm{c}}$ & $0.92 \pm 0.02^{\mathrm{d}}$ \\
\hline Moisture (\%) & $4.96 \pm 0.12^{\mathrm{a}}$ & $5.82 \pm 0.14^{\mathrm{b}}$ & $5.96 \pm 0.12^{\mathrm{c}}$ & $6.92 \pm 0.14^{\mathrm{d}}$ \\
\hline Protein $(\%)$ & $12.15 \pm 0.12^{\mathrm{a}}$ & $14.20 \pm 0.15^{\mathrm{b}}$ & $16.41 \pm 0.13^{\mathrm{c}}$ & $16.52 \pm 0.11^{\mathrm{c}}$ \\
\hline Fat $(\%)$ & $1.81 \pm 0.11^{\mathrm{a}}$ & $2.45 \pm 0.14^{\mathrm{b}}$ & $3.14 \pm 0.11^{\mathrm{c}}$ & $4.02 \pm 0.13^{\mathrm{c}}$ \\
\hline
\end{tabular}

Number of observations: $*=4$

Means bearing same superscripts row- wise do not differ significantly $(\mathrm{P}<0.01)$. 
Table.3 Sensory attributes of seasoning fryums incorporated with chicken meat (Mean \pm SE)

\begin{tabular}{|l|c|c|c|c|}
\hline \multirow{2}{*}{ Sensory attributes** } & \multirow{2}{*}{ Control } & \multicolumn{3}{|c|}{ Level of chicken meat (\%) } \\
\cline { 3 - 5 } & & $\mathbf{1 5}$ & $\mathbf{2 5}$ & $\mathbf{3 5}$ \\
\hline Appearance and colour & $6.48 \pm 0.12^{\mathrm{a}}$ & $7.12 \pm 0.12^{\mathrm{b}}$ & $7.28 \pm 0.10^{\mathrm{b}}$ & $6.58 \pm 0.11^{\mathrm{a}}$ \\
\hline Flavour & $6.42 \pm 0.10^{\mathrm{a}}$ & $6.45 \pm 0.12^{\mathrm{a}}$ & $7.18 \pm 0.15^{\mathrm{b}}$ & $6.48 \pm 0.13^{\mathrm{a}}$ \\
\hline Texture & $7.16 \pm 0.14^{\mathrm{a}}$ & $6.88 \pm 0.15^{\mathrm{b}}$ & $6.84 \pm 0.12^{\mathrm{b}}$ & $6.82 \pm 0.14^{\mathrm{b}}$ \\
\hline Crispiness & $7.28 \pm 0.11^{\mathrm{a}}$ & $7.12 \pm 0.12^{\mathrm{a}}$ & $7.10 \pm 0.14^{\mathrm{a}}$ & $6.52 \pm 0.12^{\mathrm{b}}$ \\
\hline Aftertaste & $6.90 \pm 0.22^{\mathrm{a}}$ & $6.98 \pm 0.12^{\mathrm{a}}$ & $7.00 \pm 0.12^{\mathrm{b}}$ & $6.52 \pm 0.13^{\mathrm{c}}$ \\
\hline Meat flavour intensity & - & $6.52 \pm 0.13^{\mathrm{a}}$ & $7.14 \pm 0.12^{\mathrm{b}}$ & $7.20 \pm 0.13^{\mathrm{b}}$ \\
\hline Overall acceptability & $6.98 \pm 0.12^{\mathrm{a}}$ & $6.84 \pm 0.12^{\mathrm{a}}$ & $7.10 \pm 0.14^{\mathrm{b}}$ & $6.74 \pm 0.15^{\mathrm{a}}$ \\
\hline
\end{tabular}

Number of observations: $* *=20$.

Sensory attributes were evaluated on an 8 - point descriptive scale (wherein 1 = extremely undesirable; $8=$ extremely desirable).

Means bearing same superscripts row- wise do not differ significantly $(\mathrm{P}<0.01)$.

The mean protein and fat contents also progressively increased from control to chicken meat incorporated seasoning fryums. The mean protein and fat contents of $15 \%$ and $25 \%$ chicken meat incorporated seasoning fryums did not differ significantly between them but differ significantly $(\mathrm{P}<0.01)$ from $35 \%$ chicken meat incorporated seasoning fryums sand control. The results are in agreement with the findings of Singh et al., (2014) who reported increased protein, fat and ash contents in dried snack food products with increasing levels of incorporation of meat. Similar findings are also reported by Jean et al., (1996); Rhee et al., (1999); Singh et al., (2002).

\section{Sensory characteristics}

Results of sensory evaluation of control and chicken meat based seasoning fryums are presented in Table 3. There was significant $(\mathrm{P}<0.01)$ improvement in appearance scores in all chicken meat incorporated meat based seasoning fryums as compared to control. Although, appearance scores for $25 \%$ chicken meat incorporated chicken meat based seasoning fryums were higher as compared to $15 \%$ and $35 \%$ chicken meat incorporated meat based seasoning fryums. The difference in appearance and color scours between $15 \%$ and $25 \%$ chicken meat incorporated seasoning fryums did not differ significantly between them. Appearance and colour scores between control and 35\% chicken meat incorporated seasoning fryums were also non-significant. Mean flavour scores significantly higher in $25 \%$ chicken meat incorporated seasoning fryums followed by $35 \%, 15 \%$ chicken meat incorporated seasoning fryums and control. The flavour score of between control, $15 \%$ and $35 \%$ chicken meat incorporated seasoning fryums did not differ significantly between them but differ significantly from $25 \%$ chicken meat incorporate seasoning fryums. Texture scores were decreased as increasing level of chicken meat in the formulation. Mean texture scores significantly higher for control as compared to chicken meat incorporated seasoning fryums. Texture scores between chicken meat incorporated seasoning fryums did not differ significantly between them but differ significantly from control. Crispiness scores also decreased with increasing level of chicken meat in the seasoning fryums. Crispiness scores were significantly lower in $35 \%$ chicken meat incorporated seasoning fryums. Crispiness scores between control, $15 \%$ and $25 \%$ chicken meat incorporated seasoning fryums did not differ significantly between them but differ significantly from $35 \%$ chicken meat 
incorporated seasoning fryums. After taste scores significantly higher for $25 \%$ chicken meat incorporated seasoning fryums as compared to other chicken meat incorporated seasoning fryums and control. Significantly higher meat flavour intensity scores were observed in $35 \%$ chicken meat incorporated seasoning fryums followed $25 \%$ and $15 \%$ chicken meat incorporated seasoning fryums. However, meat flavor intensity scores between $35 \%$ and $25 \%$ chicken meat incorporated seasoning fryums did not differ significantly between them but differ significantly from $15 \%$ chicken meat incorporated seasoning fryums. Significantly higher overall acceptability scores observed in $25 \%$ chicken meat incorporated seasoning fryums as compared to other chicken meat incorporated seasoning fryums and control. Overall acceptability scores between controls, $15 \%$ and $35 \%$ chicken meat incorporated seasoning fryums did not differ significantly between them.

Finding of this study has shown that the $25 \%$ chicken meat can be effectively used for preparation of a meat based seasoning frymus of an acceptable quality with improved nutritional value.

\section{References}

Anderson, R.A., Coonway, B, H. F., Pfrifer,V.F. and Griffin, E.J Jr. 1969. Gelatinization of corn grits by roll and extrusion cooking. Cereal Science Today, 14:4-12.

Anna Anandh, M., Lakshmanan, V., Mendiratta, S.K., Anjaneyulu, A.S.R. and Bisht, G.S. 2005. Development and quality characteristics of extruded tripe snack from buffalo rumen meat and corn flour. Journal of Food Science and Technology, 42:263267
AOAC. 1995. Official Methods of Analysis, $16^{\text {th }}$ ed., Association of Official Analytical Chemists, Washington DC, USA.

Barrett, A.H. and Ross, E. 1990. Correlation of extrudates infusibility with bulk properties using image analysis. Journal of Food Science. 55:1378-1382.

Breen, M.D., Seyam, A.A. and Banasik, O.J. 1977.The effect of mill by product and soy protein on the physical characteristics of expanded snack foods. Cereal Chemistry, 54:728-736.

Cheftel, J.C. 1986. Nutritional effects of extrusion cooking. Food Chemistry, 20:263-283.

Davidson, V.J., Paton, D., Biosady, L.L. and Rubin, L.R. 1984. A model for mechanical degradation of wheat starch in a single screw extruder. Journal of Food Science, 49:1154-1157.

Gomez, M.H. and Aguilera, J.M. 1983. A physico chemical model for extrusion of corn starch. Journal of Food Science, 49:43, 63.

Jean, I.J., Work, R., Camire, M.E., Briggs, J., Barrett, A.H. and Bushway, A.A. 1996.

Selected properties of extruded potato and chicken meat. Journal of Food Science, 61:783-789.

Kavya Reddy, M., Aparna Kuna, Lakshmi Dev, N., Krishnaiah, N., Charanjit Kaur, and Nagamalleswari, Y. 2014. Development of extruded Ready-To-Eat (RTE) snacks using corn, black gram, roots and tuber flour blends. Journal of Food Science Technology. 51:19291937.

Keeton, J.T. 1983. Effect of fat and Nacl / Phosphate levels on the chemical and sensory properties of pork patties. Journal of Food Science, 48: 878 - 881.

Kumar, P., Chatli, M.K., Metha, N., Malve, O.P., Verma, A.K. and Kumar, D. 2016. Quality attributes and storage stability 
of chicken meat biscuits incorporated with wheat and oat bran. Journal of Food Quality, 39: 649-657.

Machado, M.F., Oliveria, F.A.R., Gekas, V. and Singh, R.P. 1998. Kinetics of moisture uptake and soluble solids loss by puffed breakfast cereals immersed in water. International Journal of Food Science and Technology, 33:225-237.

Mittal, P. and Lawrie, R.A. 1984. Extrusion studies of mixture containing certain meat offals. Part 1. Objective properties. Meat Science, 10:101-116.

Mittal, P. and Lawrie, R.A. 1986. Extrusion studies of mixture containing certain meat offals. Part 2: Texture properties. Meat Science, 16:143-160.

Park, J., Rhee, K.S., Kim, B.K. and Rhee, K.C. 1993. High protein texturized products of defatted soy flour, corn starch and beef: Shelf life, physical and sensory properties. Journal of Food Science, 58:21-27.

Rhee, K.S., Cho, S.H. and Pradahn, A.M. 1999. Composition, storage stability and sensory properties of expanded extrudates from blends of corn starch and goat meat, lamb, mutton, spent fowl meat, or beef. Meat Science, 52: 135-141.
Singh, P., Sahoo, J., Chatli, M.K. and Biswas, A.K. 2014. Optimization of the level of rice flour in chicken meat caruncles. Indian Journal of Veterinary Research, 23:10 - 20.

Singh, V.P., Sanyal, M.K., Dubey, P.C. and Mendiratta, S.K. 2011. Quality assessment of vacuum packaged chicken snacks stored at room temperature. Journal of Storage Products and Post-Harvest Research, 2:120-126.

Singh, V.P., Dubey, P.C. and Sanyal, M.K. 2002. Quality of chicken snack affected by the level of spent hen meat. Indian Journal of Poultry Science, 37:73-77. Snedecor, G.W. and Cochran, W.G. (1989). Statistical Methods. $8^{\text {th }}$ edn, Oxford and IBH Publishing CO., Calcutta.

Sriburi, P. and Hill, S.E. 2002. Extrusion of cassava starch with either variations in ascorbic acid concentration or $\mathrm{PH}$. International Journal of Food Science and Technology, 35: 141-154.

Wen, L.F., Rodies, P. and Wasserman, B.P. 1990. Starch fragmentation and protein insolublization during twin screw extrusion of corn meal. Cereal Chemistry, 67: 268-275.

\section{How to cite this article:}

Anna Anandh, M. 2017. Development of Meat based Seasoning Fryums using Chicken Meat and Rice Flour Blends. Int.J.Curr.Microbiol.App.Sci. 6(6): 2112-2119. doi: https://doi.org/10.20546/ijcmas.2017.606.250 